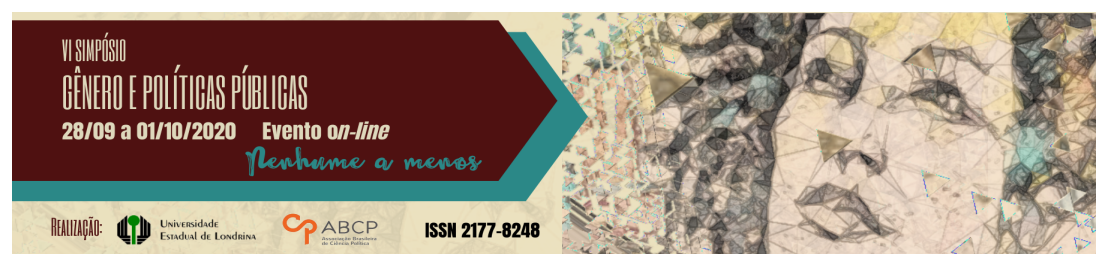

\title{
Mulheres e enquadramentos de suas formas de vida nas fotografias do Farm Security Administration e do Bolsa- Família ${ }^{1}$
}

Ângela Cristina Salgueiro Marques²; Cícero Pedro Leão de Almeida Oliveira ${ }^{3}$

\section{Resumo}

A pesquisa analisa comparativamente dois conjuntos de imagens: fotografias jornalísticas que retratam mulheres beneficiadas pelo Bolsa-Família, publicadas entre 2003 e 2015, em jornais e revistas de ampla circulação nacional; e imagens oficiais do Farm Security Administration, retiradas de coletâneas e do site photogrammar.yale.edu. Busca-se construir uma abordagem teórico metodológica que suscite um olhar atento aos pequenos detalhes, questionando julgamentos e assertivas morais preexistentes. Para tanto, nos apoiamos sobretudo nas reflexões teóricas de Jacques Rancière e DidiHuberman, que buscam caracterizar o trabalho das imagens como montagens intervalares capazes de tornar perceptíveis as hierarquias e assimetrias que os discursos dominantes se esforçam em apagar. Objetiva-se questionar as formas de legibilidade e inteligibilidade frequentemente associadas às imagens de sujeitos em situação de vulnerabilidade, em prol de apropriações que nos tornem sensíveis às governamentalidades que distribuem desigualmente os espaços, as falas, os tempos e as exposições e aparições da alteridade.

Palavras-chave: mulheres empobrecidas, políticas sociais, imagens fotográficas.

\section{Women and the framing of their forms of life in the photographs of the Farm Security Administration and Bolsa- Família}

\footnotetext{
${ }^{1}$ Este trabalho resulta de pesquisa apoiada pelo CNPq e pela FAPEMIG.

2 UFMG. Doutora em Comunicação Social pelo PPGCOM/UFMG e Professora Associada do mesmo Programa. E-mail: angelasalgueiro@gmail.com

3 UFMG. Mestre em Comunicação Social pelo PPGCOM/UFMG. E-mail: ciceropedro17@gmail.com
}

GT 11 - Gênero, políticas de desenvolvimento e combate à pobreza 


\begin{abstract}
The research comparatively analyzes two sets of images: journalistic photographs that portray women benefited by the Bolsa Família Program, published between 2003 and 2015, in newspapers and magazines with wide national circulation; and official images from the Farm Security Administration, taken from archives and from the photogrammar.yale.edu website. We seek to build a theoretical and methodological approach that raises an attentive look at the small details, questioning preexisting moral judgments and assertions. Therefore, we rely mainly on the theoretical reflections of Jacques Rancière and Didi-Huberman, who seek to characterize the work of images as interval montages capable of making the hierarchies and asymmetries perceptible that the dominant discourses strive to erase. The objective is to question the forms of legibility and intelligibility often associated with the images of subjects in situations of vulnerability, in favor of appropriations that make us sensitive to governmentalities that unevenly distribute spaces, speeches, times and exhibitions and appearances of otherness.
\end{abstract}

Keywords: impoverished women, social policies, photographic images.

\title{
Introdução
}

O que significa olhar para uma imagem com desconfiança? Olhar sem aderir a um julgamento precipitado, permitindo a exploração dos elementos que compõem o quadro, indagando sobre os sujeitos que ali estão expostos, elencando elementos e detalhes antes de "classificar" seu conteúdo e rotular seu enunciado? Tais questionamentos nos guiaram na análise comparativa aqui construída de modo a valorizar um entendimento de como operam as imagens e de que tipo de legibilidade podem conferir ao mundo e à alteridade. Compreendemos uma imagem como "resultado de um dispositivo de visibilidade que regula o estatuto dos corpos representados e o tipo de atenção que merecem" (RANCIÈRE, 2012, p. 96). Assim, os sentidos evocados por uma imagem podem ser melhor apreendidos quando trazemos para junto dela outras imagens e outros enunciados que nos auxiliem a investigar como funcionam as operações e dispositivos que regulam o aparecimento dos sujeitos e o tipo de atenção e consideração que lhes é destinada. 
Em nossas análises, veremos que "aparecer" não se reduz a adquirir visibilidade, mas envolve alterar o modo como sujeitos são percebidos e reconhecidos diante dos outros, o que demanda um deslocamento do olhar, uma outra forma de imaginar a alteridade e de considerar as formas de vida daqueles que se apresentam diante de nós (MARQUES, 2017).

Nos trabalhos recentes de Jacques Rancière (2013, 2018, 2019) e Georges Didi-Huberman (2014, 2016), as operações que constituem as imagens revelam uma tensão entre regimes de visiblidade e controle das vidas que visam o apagamento e regimes que privilegiam o "aparecer" insurgente das existências. Ambos se preocupam com os modos de tornar legíveis e inteligíveis formas de vida na imagem. Eles ressaltam que a capacidade de "aparecer" de sujeitos minoritários manifesta-se em uma espécie de montagem que, ao reunir várias imagens, pode revelar a fratura causada por representações preconceituosas que aprofundam desigualdades. Para eles, as imagens tendem a revelar as operações que as sustentam quando vistas em conjuntos, em mosaicos ou constelações que permitem que o espectador apreenda os hiatos e intervalos responsáveis por deslocar e reconfigurar o olhar.

Assim, a operação intervalar das imagens cria "aparências" que desafiam o modo hierárquico de apresentação da realidade, rearranjando a legibilidade das imagens. É no espaço "entre" imagens que atua o que Rancière (2019, p. 51) chama de "máquina de desmontagem do olhar" e da inteligibilidade do que estava programando para poder ser visto. Ao conceber as imagens enquanto operações intervalares de desierarquização, Rancière estaria procurando uma maneira de anular um modo consensual e hierárquico de pensamento e produção de inteligibilidade a partir do trabalho político da arte. A indeterminação acionada por essa máquina, ou seja, a impossibilidade de fixar o destino e a significação das imagens, impede que elas sejam a mera expressão de uma situação ou de um acontecimento determinado. 
Em publicação anterior (OLIVEIRA; MARQUES, 2019), nós apresentamos análises comparativas entre fotografias sobre dois projetos sociais: o americano Farm Security Administration (FSA) 4 e o brasileiro Bolsa-Família. De formas distintas, as duas iniciativas enfatizam o aspecto precário dos fotografados, diminuindo a possibilidade de existência, na imagem, de uma vida além da vulnerabilidade. $\mathrm{O}$ foco anterior foram as imagens dentro ou em torno da casa, já que o lar é o espaço primordial para o enquadramento analisado.

Nesta apresentação, continuaremos a comparação a partir de novas análises que ressaltem mais nuances sobre o enquadramento de pessoas em vulnerabilidade assistidas por programas sociais, indagando se há a possibilidade de uma agência mais potente em projetos foto-documentais-jornalísticos pautados pela construção de discursos essencialistas. Sem nos determos diretamente em um local, como o lar e seus arredores, nós comparamos imagens com composições ou temas paralelos, desde a presença de enquadramentos dentro dos enquadramentos a partir das laterais de objetos ou aberturas de portas, até imagens com sorrisos ou bebês 5 .

4 O FSA foi uma iniciativa do governo dos EUA para ajudar os trabalhadores rurais em dificuldade durante a depressão nos anos 1930. Entre as medidas de auxílio, estão as seguintes: "empréstimos a baixo juro para compra de terra, desenvolvimento de estudos sobre preservação dos solos e criação de quintas experimentais e de explorações comunitárias, que visavam dar emprego aos trabalhadores errantes" (SOUZA, p. 110). A sessão histórica do organismo, liderada por Roy Stryker, foi responsável por milhares de fotos dos trabalhadores americanos nos anos 1930 e 1940, produzindo aproximadamente 175 mil negativos. Diferentes realidades foram registradas pelos fotógrafos contratados, mas as mais emblemáticas são caracterizadas por um teor de denúncia e/ou consciência social, demonstrando a vida difícil de pessoas humildes e o seu processo de superação.

${ }^{5}$ A fotografia social do FSA e o fotojornalismo sobre o Bolsa Família foram produzidos em contextos distintos (um jornalístico e outro governamental). No entanto, mesmo no catálogo do FSA houve espaço para fotos estritamente institucionais, geralmente usadas em manuais e publicações do governo, e outras que tensionam e se distanciam do aspecto institucional do projeto. Além disso, as orientações editoriais que os fotógrafos americanos recebiam do coordenador Roy Stryker - e que serão apresentadas a seguir - ainda ecoam na produção de fotografias sobre pessoas empobrecidas que ocorreu posteriormente, inclusive no fotojornalismo do BolsaFamília. A maioria das imagens aqui levantadas - americanas e brasileiras - não são 
O objetivo não é apresentar fotos idênticas que foram registradas em tempos bem distantes (ainda que algumas dessas imagens parecidas estejam aqui), mas produzir uma aproximação e um diálogo que demonstre as perspectivas ideológicas que nortearam as produções dessas fotografias, partindo dos registros para questões amplas. Vale pontuar que a noção de enquadramento utilizada aqui não está somente na acepção fotográfica, mas consiste também em "uma determinada maneira de organizar e apresentar uma ação [que] leva a uma conclusão interpretativa acerca da própria ação" (BUTLER, 2018, p. 23). A partir das repetições de determinados padrões e regularidades, foi possível constatar a normatização dos corpos em situações vulneráveis, especialmente as mulheres, como se alguns fossem mais dignos do que outros, apreendendo as pessoas atendidas por programas sociais em arquétipos da precariedade. O nosso gesto é esmiuçar esse enquadramento, retirá-lo da invisibilidade, desconstruindo o aspecto construído de tais registros, como argumenta Butler:

As normas do humano são formuladas por formas de poder que buscam normalizar as versões específicas do humano, em detrimento dos outros, fazendo distinções entre os humanos ou amplificando o campo do não humano, segundo seu desejo. Perguntar como essas normas são instaladas e normalizadas é o começo do processo de não tomar a norma como alguma coisa certeira, de não esquecer de perguntar-se como ela foi instalada e representada e a qual ponto. Para aqueles que são invisibilizados e humilhados pela norma que eles deveriam incorporar, a luta se torna uma batalha corporal pela condição de reconhecimento, uma insistência/perseverança pública de existir e de ter importância (BUTLER, 2018, p. 97).

estritamente institucionais - já que essas imagens do governo geralmente valorizam famílias nucleares -, mas tampouco rompem com os enquadramentos generalizantes sobre a pobreza. 
Ou seja, não se trata somente de esmiuçar o aspecto formal das imagens, mas de abordar como a estratégia operativa em volta das imagens pode afetar a forma como as vidas dos retratados são percebidas socialmente.

Pensando na tradição da fotografia, esse desenquadramento do enquadramento é essencial, pois a fotografia dominante, principalmente a documental e jornalística do Bolsa-Família e do FSA, segue uma ideologia da invisibilidade, já que a câmera fotográfica busca "produzir a perspectiva renascentista e não visa isto por acaso: toda a nossa tradição cultural logrou identificar essa construção perspectiva com o efeito de "real" e por isso a fotografia faz basear o seu ilusionismo homológico na ideologia que está cristalizada nessa técnica" (MACHADO, 1984, p. 66). O fotojornalismo acerca do BolsaFamília não rompe com esse modelo; ele busca claramente criar um efeito do real ao não mobilizar a indecisão, ao focar na frontalidade equilibrada dos corpos, em uma postura de documento oficial, cristalizando uma leitura homogênea dessas pessoas e eliminando as suas singularidades ou personalidades. Contudo, a comparação com as imagens da FSA nos oferece a possibilidade de dialetizar as imagens, nos oferecendo a oportunidade de mostrar como as vidas precárias podem figurar na montagem, ou seja, podem ser apreendidas em sua dignidade.

\section{Percurso Metodológico}

Nós construímos dois bancos de dados: um com imagens fotojornalísticas que retratam mulheres beneficiadas pelo BolsaFamília, publicadas entre 2003 e 2015, em jornais e revistas de ampla circulação nacional; e o outro com imagens oficiais do FSA, retiradas de coletâneas e do site photogrammar.yale.edu, após uma imersão nas 83100 imagens disponibilizadas no link. Ainda que o FSA seja um projeto governamental que encomendou as fotografias de trabalhadores rurais para documentar a "recuperação" dos assistidos, 
e as imagens midiáticas do Bolsa-Família não sejam feitas a pedido do governo, consideramos que os dois conjuntos de imagens possuem uma dimensão editorial bem definida: há instruções editoriais muito claras que guiam os enquadramentos dos fotógrafos, ainda que alguns deles desafiem essas diretrizes. No caso do Bolsa-Família, analisamos em outro trabalho (MARQUES; MORICEAU, 2018) as imagens feitas pelo Ministério do Desenvolvimento Social e publicadas no site oficial e em revistas de divulgação. Mas, com raras exceções, são imagens mais padronizadas de famílias tradicionalmente compostas, "modelos" de conduta a serem seguidos. A aproximação entre os arquivos de imagens fotojornalísticas nos pareceu mais promissor para evidenciar como o diálogo entre imagens pode nos tornar sensíveis ao registro das vidas precárias que, por mais que reflitam as diretrizes de enquadramentos subalternizantes, podem ainda evidenciar agências e deslocamentos menores, porém desafiadores e potentes.

Durante a análise comparativa, percebemos algumas diferenças que dizem muito sobre as particularidades entre os dois projetos. No FSA, por exemplo, há imagens ao ar livre, com pessoas na estrada ou realizando trabalhos braçais, o que é incomum nas imagens brasileiras, justamente porque o FSA buscava incentivar o trabalho agrícola de fazendeiros pobres. A assistência brasileira tinha outro viés, buscando amenizar a pobreza a partir de recursos específicos. No entanto, se percebe claramente um diálogo entre várias outras imagens no recorrente foco em uma espécie de iconografia da pobreza - que pode ser mais digna ou mais rústica, como veremos posteriormente -, e na centralização da mulher nessa construção. Assim, nesta comunicação, apresentamos comparações principalmente com imagens de mulheres, para investigar as diferentes maneiras através das quais essas fotografias normatizaram o corpo feminino nas realidades registradas.

Nosso percurso metodológico é guiado pela combinação dos gestos analíticos empreendidos por Rancière (2019) e Didi-Huberman (2016), que tematizam o "aparecer" de sujeitos vulneráveis nas imagens a partir de um momento de dissenso, de assimetría, de 
deslocamento que produz intervalos e, a partir desses intervalos, podemos perceber as disparidades, as tensões e fraturas que permaneciam ocultas sob o manto de um registro representativo, causal e hierárquico. Didi-Huberman (2016) ressalta o trabalho das imagens em nos tornar sensíveis à vida dos povos a partir do que aparece como falhas, intervalos e brechas nas imagens. A figura do intervalo é produtiva também para Rancière, que destaca a importância de "descontinuar" as narrativas consensuais que tendem a explicar o mundo por meio de discursos e imaginários consolidados. Por sua vez, Rancière caracteriza o aparecer (apparaître) como um gesto estético e político que promove uma outra forma de estruturação do "pensável", envolvendo a alteração de um regime de percepção, de leitura e de escuta por meio do qual elementos diversos se justapõem e se atritam de modo a permitir um deslocamento de nossa posição em relação ao modo como apreendemos, percebemos e respondemos às demandas do outro e aos eventos do mundo.

Insisti sobre a positividade da aparência, sobre o fato de que a aparência é um aparecer. A aparência é a criação de uma cena sobre a qual as coisas são visíveis, mas visíveis de uma certa forma, pois ocorre uma reorganização do campo do visível, desafiando a ordem hierárquica (RANCIÈRE, 2019, p.46).

De modo mais amplo, parece que Rancière está interessado em como as imagens podem nos fazer pensar acerca de um reposicionamento dos corpos, de um deslocamento de avaliações muito apressadas e de julgamentos fundados em pre-conceitos: haveria uma forma de analisar imagens que pudesse ir além de uma apreensão rápida e pautada pelo já dado, pelo comumente aceito como válido? Como encontrar "uma forma de interromper a máquina da explicação das coisas" (RANCIÈRE, 2018b, p. 17)? "Qual tipo de operação vai mudar essa distribuição do visível e do pensável?" (RANCIÈRE, 2019, p. 50). 
A aparência não é o contrário da realidade, mas a cena de sua manifestação (...): o fato de fazer aparecer o que não aparecia, ou de fazer aparecer de forma diferente o que aparecia sob um certo modo de visibilidade e inteligibilidade, sabendo que tudo se joga na apresentação daquilo que aparece (RANCIÈRE, 2018b, p. 17).

O trabalho da imagem consiste, assim, em produzir um arranjo, um reenquadre, uma reorganização de formas perceptivas dadas, uma recomposição da ordem que sustenta uma dada narrativa, uma montagem que evidencie um intervalo, um espaço que torna possível habitar o "entre".

Eis uma primeira dimensão importante de nosso percurso metodológico: considerar que os intervalos criados a partir do contato entre dois diferentes conjuntos de imagens (elaboradas com finalidades distintas, em contextos distintos e atravessadas por diverentes temporalidades e espacialidades) desafiem nosso olhar a percorrer o espaço "entre" imagens, como um movimento incessante de aproximação e distanciamento, mas não necessariamente linear. O que interessa a Rancière é o modo como as imagens podem produzir esse jogo de intervalos ao serem articuladas fora da lógica da representação, escapando a uma hierarquia da ação e fortalecendo uma prática de montagem dissensual. É importante precisar que a montagem para Rancière é uma ação que, ao mesmo tempo, aproxima várias imagens, mas confere também importância à singularidade de uma única imagem, sobretudo quando ela introduz uma linha de fuga em relação ao desdobramento horizontal de um enunciado no qual impera a causalidade consensual. São os arranjos indeterminados entre imagens que se associam, por sua vez, a palavras, temporalidades e outros registros que se destacam na abordagem que Rancière conferè à imagem, delinenando-a como uma cena polêmica.

A segunda dimensão estruturante de nosso percurso metodológico relaciona-se ao gesto de, a partir da montagem dissensual, "dialetizar o visível” (DIDI-HUBERMAN, 2016), ou seja, de 
deslocar a representação, lançando perguntas às imagens, demorandonos em sua contemplação e produzindo, nesse processo, novos enquadramentos e novas possibilidades interpretativas. Dialetizar envolve tornar sensíveis e legíveis as "falhas, os lugares e os momentos por meios dos quais os povos, ao declararem sua impotência, afirmam, ao mesmo tempo, o que lhes falta, o que os expõe ao desaparecimento e o que desejam" (DIDI-HUBERMAN, 2016, p. 422).

Segundo Didi-Huberman (2016, p. 405), "dialetizar o visível" destaca a "potência de legibilidade dos acontecimentos sensíveis" através das imagens, ou seja, a potência de tornar legível a dialética de uma falha, de algo que foi reprimido, de uma vida que foi desumanizada e silenciada. Assim, dialetizar o visível implica também "tornar sensível" (rendre sensible), isto é, tornar acessível aquilo que nossos sentidos e inteligências nem sempre conseguem "ler" ou conferir sentido, permanecendo como indício, resto, algo que é geralmente desconsiderado pelo olhar. Mas tornar sensível também significa passar a considerar algo que nos escapava, sobretudo algo que não era "legível" até então acerca da vida dos povos e de sua história (DIDI-HUBERMAN, 2016).

Sob esse aspecto, Rancière e Didi-Huberman possuem o interesse comum em evidenciar como as imagens, dialeticamente, tornam sensíveis - acessíveis, legíveis e dignas de consideração - a vida e a sobrevivência dos povos, ao mesmo tempo em que elas evidenciam situações que os expõem à violência, ao silenciamento e, justamente por isso, demandam outras formas de acolhimento, consideração e hospitalidade nas imagens. Tornar sensível e dialetizar o visível através da montagem intervalar são operações que nos auxiliam a encontrar os elementos da imagem que permitem produzir uma aproximação, um avizinhamento mais demorado entre espectador e alteridade presente na imagem. O intuito é despertar no espectador e nos processos de circulação das imagens novos modos de percepção dos corpos e das múltiplas espacialidades e temporalidades 
da cena a partir da qual figuram e se erguem, dialeticamente e dissensualmente, os rostos que nos interpelam.

\section{As imagens, seus pontos de aproximação e tensão}

É comum nos dois projetos fotográficos a frontalidade em grupo no lar, repetindo as configurações do retrato doméstico. Como já apontado por Marie-Claire e Pierre Bourdieu (2006), as imagens frontais reforçam os papéis sociais almejados pelos retratados, como o marido, o militar etc, e não tanto as suas singularidades. A suposta invisibilidade do ponto de vista da câmera nos retratos só intensifica a condição social dessas imagens. No caso do nosso corpus, o paradoxo aumenta, pois os papéis sociais não são delimitados por quem está na frente da câmera, já que a imagem não é um retrato familiar, mas por uma perspectiva geral, seguida por quem têm a câmera, que busca reforçar a condição vulnerável desses corpos, em detrimento de outras possibilidades. No caso do FSA, os fotógrafos recebiam orientações rígidas do coordenador Roy Stryker, como apontado por Inês Costa:

A primeira instrução era de fotografar a fazenda ou o fazendeiro em uma situação desesperadora, propositalmente mostrando a pobreza por meio do registro de "prédios degradados" ou "roupas pobres". As próximas fotos devem contar uma história de sucesso, retratando cenas roteirizadas de agricultores interagindo com agentes da FSA e recebendo empréstimos até que terminassem com um momento claro de sucesso, como "De volta à fazenda - salvo - aliviado e feliz". Alguns fotógrafos receberam, além disso, instruções para fotografar pessoas específicas, a maioria das quais já tinha alguma relação com o programa de reabilitação (COSTA, 2019, s/p).

A idéia de registrar encontros entre representantes do governo e os assistidos é presente nas imagens dos dois projetos, com o contraste entre os ternos e as roupas humildes saltando aos olhos. Exemplos abaixo: 


\section{Imagem 1}

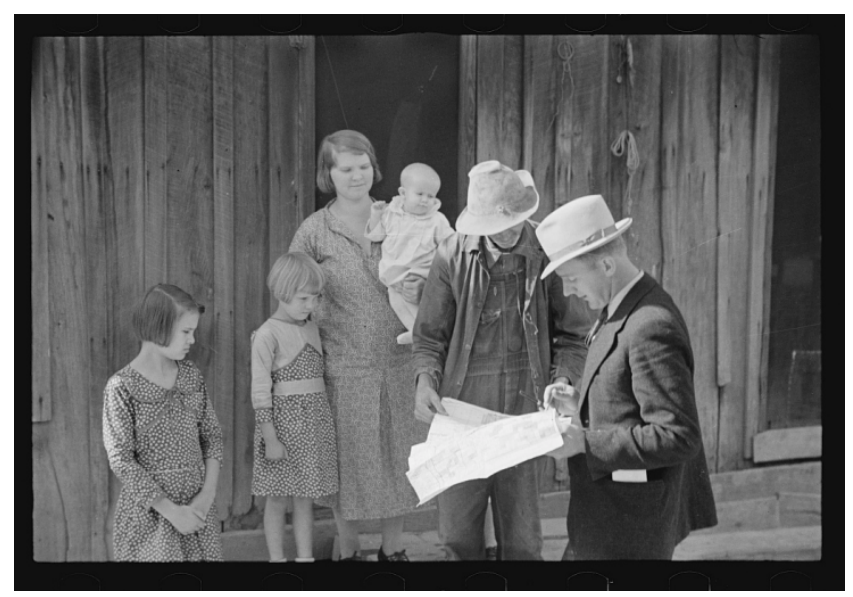

Foto: Theodor Jung, 1935. Legenda: Client talks things over with the government representative, Brown County, Indiana. Fonte: http://photogrammar.yale.edu/records/index.php?record=fsa1997013965/P $\underline{\mathrm{P}}$

\section{Imagem 2}

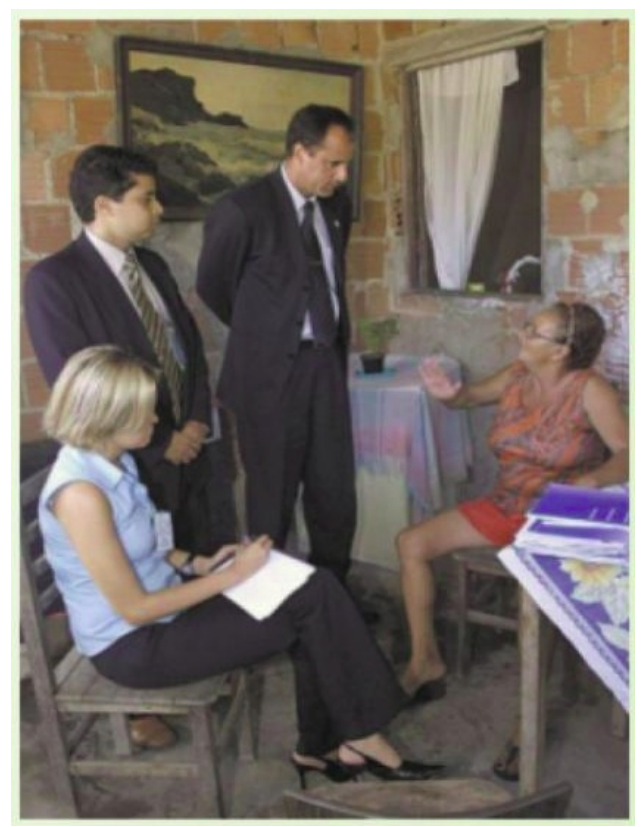


Legenda: Técnicos do Bolsa-Família visitam beneficiária do programa em São Francisco do Itabapoana. Fonte: GOIS, Antônio. "Estudo propõe universalizar Bolsa-Família”. Folha de São Paulo, 29 nov. 2004.

Alguns fotógrafos conseguiam produzir imagens distantes das instruções governamentais de Stryker, mas isso geralmente resultava em fortes atritos entre eles e o coordenador. Além disso, o foco em uma precariedade visual, com uma aura de dignificação, também era presente em algumas fotografias autorais. No geral, tanto nos EUA quanto no Brasil, a frontalidade era bem comum, como analisamos anteriormente (OLIVEIRA; MARQUES, 2019), com a maioria dos corpos enfileirados lateralmente. Quando o grupo é grande, geralmente as pessoas sentadas ou menores, como os filhos, ficam na frente dos mais altos, mas ainda muito próximos, quase colados, uns aos outros. As duas imagens abaixo têm uma composição menos comum, pois é grande a distância entre as pessoas. $\mathrm{O}$ trabalho com a profundidade de campo se torna mais visível devido ao contraste entre o homem, no primeiro plano da imagem, e a mulher e as crianças, no segundo plano, ao fundo.

\section{Imagem 3}

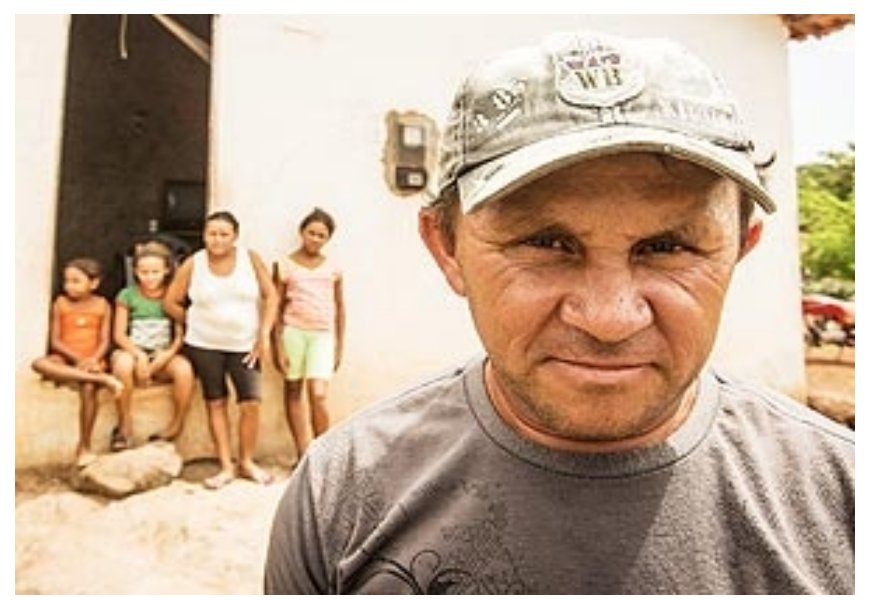

Foto: Eduardo Anizelli/Folhapress. Legenda: O agricultor Antônio da Conceição Sousa, 38, que vive na pequena cidade de Joaquim Pires, interior do Piauí. Fonte: CARVALHO, Daniel. "Famílias deixam pobreza extrema, mas ainda enfrentam dificuldades; leia histórias", Folha de São Paulo, 
03/02/2013.

Imagem

no

endereço:

https://m.folha.uol.com.br/poder/2013/02/1220711-familias-deixam-

pobreza-extrema-mas-ainda-enfrentam-dificuldades-leia-historias.shtml

\section{Imagem 4}

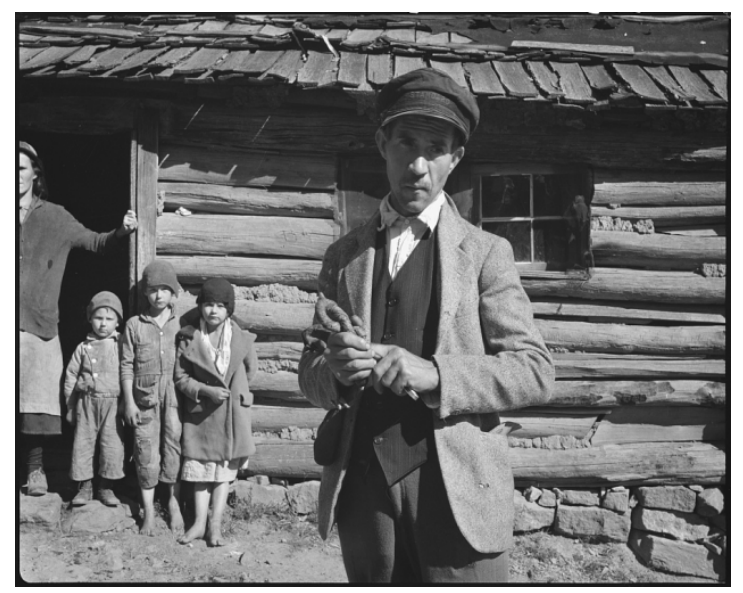

Arthur Rothstein, 1935. Legenda: Sam Corbin, who will be resettled on new land. Shenandoah National Park, Virginia. Fonte: http://photogrammar.yale.edu/records/index.php?record=fsa1998017538/P $\underline{\mathrm{P}}$.

O flexibilização da frontalidade torna mais clara as perspectivas gerais desses projetos fotográficos. O homem, na frente, está mais distante da casa, e permanece um indivíduo solitário, cujo rosto, ou identidade, o leitor consegue discernir. As mulheres, no fundo, estão mais próximas das crianças e da própria casa; a brasileira com o rosto desfocado e a americana com o rosto cortado. Ou seja, não é possível discernir um traço de suas personalidades. Ao homem, é possibilitado um distanciamento do lar e a construção de uma individualidade mais saliente. Já a mulher não deve ficar muito distante dos filhos e da casa. Essas posições mostram como a mulher, nesses enquadramentos, é colocada em uma posição doméstica e materna, não apresentando outras possibilidade de vida. Na legenda da imagem brasileira, o homem tem uma função específica: agricultor. No entanto, na mesma reportagem, a maioria das legendas das imagens de mulheres não 
apresentam nenhuma função. Das quatro mulheres, três - Luiza de Franca Sousa, Joelina Maria de Sousa, Francisca Oliveira - são identificadas como desempregadas. Somente a legenda de Antônia Pereira Galvão não tem o termo, mas também não apresenta nenhuma função. Ou seja, ainda que quase todos os personagens da matérias sejam mulheres, somente ao homem é identificada uma função além do lar, que é este homem mais distante da casa na imagem acima.

O foco na mulher nas narrativas sobre a precariedade é recorrente, pois uma forma apresentar a vulnerabilidade de um grupo familiar é apresentar as condições precárias de um lar, sendo que, neste lar, a mulher é considerada a força básica principal. No BolsaFamília, o cartão de acesso ao benefício é colocado no nome da mulher, considerada responsável pela sua família. Devido ao acúmulo de tarefas do lar, uma inserção no mercado de trabalho se torna mais difícil. No debate público, o paradoxo continua.

Se, por um lado, as condições básicas para que tais mulheres construam dimensões importantes de sua cidadania e de sua autonomia são promovidas pelas redes de assistência social, por outro lado, há barreiras concretas que dificultam sua inclusão política e social derivadas, sobretudo, de um entendimento comum e naturalizado que aponta os indivíduos em situação de pobreza como "massa inútil de despossuídos e dependentes", incapazes de contribuir para movimentar as engrenagens da produção e do consumo neoliberais. Nesse sentido, a imprensa compreende um dos contextos que fomenta processos de demarcação de lugares e falas a esses sujeitos, assim como promovem seus enquadramentos e molduras (MARQUES; FREITAS; OLIVEIRA, 2019, p. 30).

Nas fotojornalismo, as mulheres geralmente são fotografadas dentro ou nos arredores de suas casas humildes, cujos sinais visuais de pobreza são preservados, reforçando os enquadramentos. Dois exemplos abaixo. 


\section{Imagem 5}

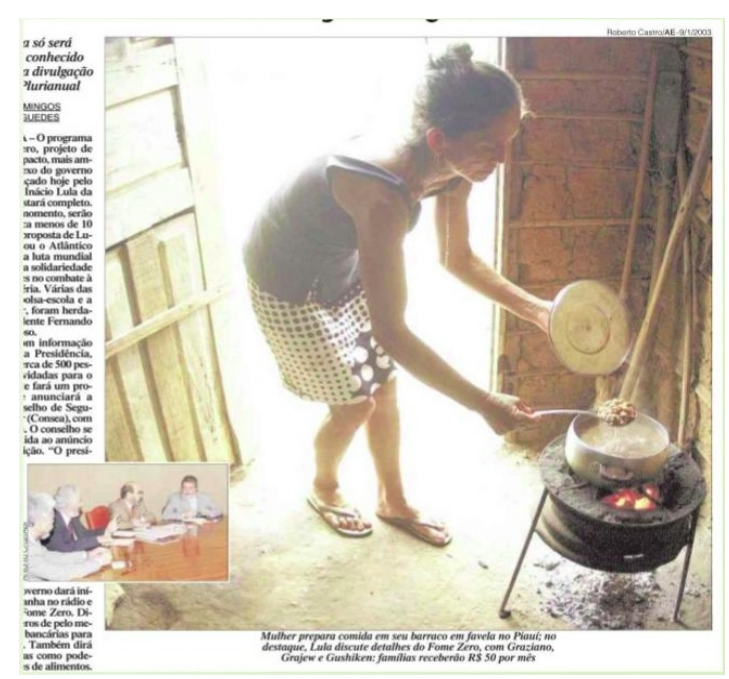

Legenda: Mulher prepara comida em seu barraco, em favela no Piauí. No destaque, Lula discute detalhesdo Fome Zero com Graziano, Grajew e Gushiken: famílias receberão R $\$ 50$ por mês. Foto: RobertoCastro/AE. Fonte: DOMINGOS, João; GUEDES, Gisele. "Fome Zero começa hoje, ainda incompleto", O Estado de S. Paulo, Nacional, 30/01/03, p.8. Imagem no endereço: https://acervo.estadao.com.br/pagina/\#!/20030130-39916-nac-4pol-a4-not. Acesso em: 20 out. 2019. 


\section{Imagem 6}

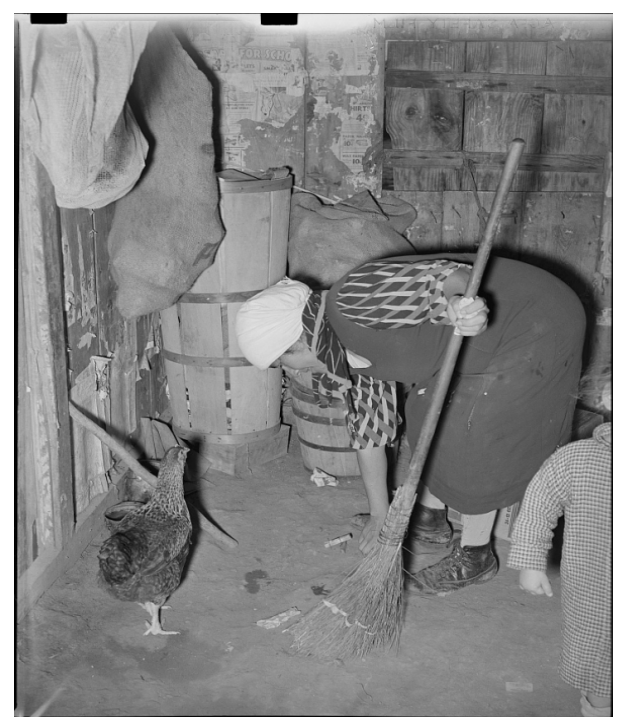

Russell Lee, 1939. Legenda: Mexican women sweeping dirt floor. Chickens are found in many of the Mexican houses. Crystal City, Texas. Fonte: https://www.loc.gov/resource/fsa.8b21070/

O corpo encurvado é bem comum nessas fotografias, principalmente no FSA, geralmente indicando um trabalho árduo, como preparo de refeição ou limpeza da casa, que são as ações mais registradas. Nas imagens acima, o espaço em volta dos corpos também é importante para intensificar a condição da pobreza, condição esta que se sobrepõe aos próprios rostos das mulheres, que, novamente, não conseguimos discernir. As paredes das duas imagens estão distantes das construções "modernas" com tijolos e concreto. No chão, igualmente, não há cerâmicas ou pisos sofisticados. Os objetos de ação - fogão e vassoura - são mais artesanais - na foto brasileira, o fogo não é a gás, por exemplo. Essas informações visuais aliadas a corpos encurvados, sem identificação, reforçam uma suposta condição arcaica e precária, tanto das mulheres quanto do espaço onde elas habitam.

Também vale notar como elementos extratextuais influenciam na construção de significados. Na reportagem brasileira, o texto é cortado por imagens de políticos em um reunião de gabinete, o que 
"revela, em primeiro lugar, o âmbito da institucionalidade patriarcal e sua mise en scène de gestão biopolítica (homens políticos de terno, em uma sala confortável, definindo as formas de auxílio a famílias e mulheres vulneráveis)" (MARTINO; MARQUES, 2020, p. 45). Na imagem americana, a legenda é a seguinte: "Mexican women sweeping dirt floor. Chickens are found in many of the Mexican houses. Crystal City, Texas". Analisando essa imagem, Lisa H. Kaplan (2015) aponta que, apesar do corpo encurvado ter proeminência na imagem, a legenda desloca a atenção para a galinha e o chão sujo, relacionando o cotidiano mexicano, já que a foto é de uma mulher mexicana, com a sujeira, principalmente quando se pensa que a existência de pássaros e animais em casa aumenta as possibilidades de doenças.

A autora argumenta que as imagens mais institucionais de pessoas brancas atendidas pelo FSA muitas vezes apresentavam uma espécie de pobreza em processo de superação devido a assistência do governo. Esta possibilidade era menos comum nas imagens com mexicanos, como se esses não fossem capazes de superar a pobreza e entrar no programa FSA. Kaplan não analisa as imagens abaixo, mas vamos destacá-las pois as mulheres em cena apresentam corpos encurvados, semelhante a última imagem brasileira destacada, porém criam significado distintos. 


\section{Imagem 7}

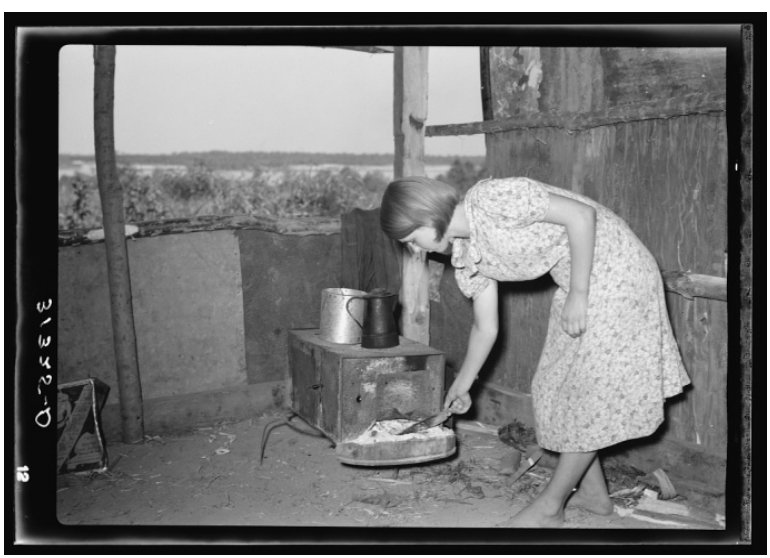

Russell Lee, 1938. Legenda: Girl tending fire in shack home. Tin Town, Caruthersville, Missouri. Fonte: http:// photogrammar.yale.edu/records/index.php?record=fsa2000012490/P $\mathrm{P}$

\section{Imagem 8}

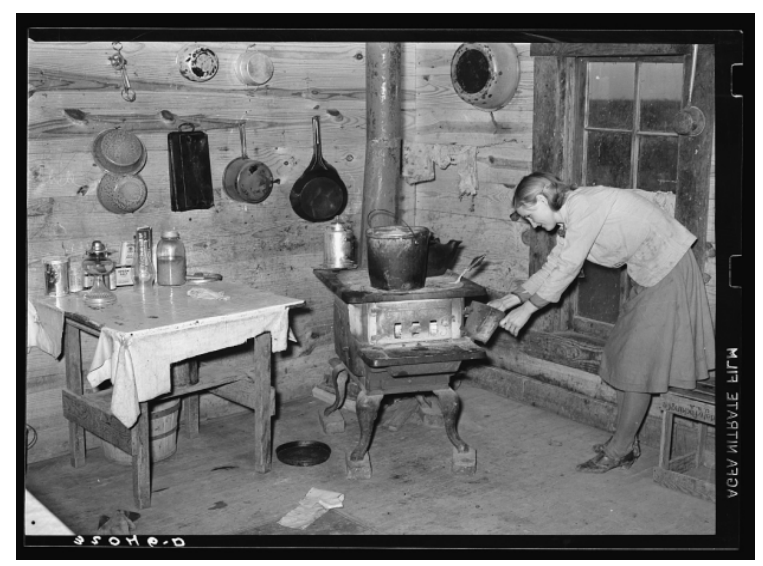

Russell Lee, 1939. Legenda: Home of share-cropper living near Merigold, Mississippi. Background photo, Sunflower Plantation. Fonte: http:/ / photogrammar.yale.edu/records/index.php?record=fsa2000013229/P $\mathrm{P}$

Ambas as casas são humildes, com mulheres encurvadas realizando tarefas domésticas. No entanto, na segunda foto, o ambiente está muito mais organizado do que a fotografia brasileira e a 
imagem com a mulher mexicana. Houve um esforço de preservar uma casa organizada, ainda que pobre. A primeira imagem já apresenta alguns sinais mais salientes de precariedade, como o chão mais desorganizado. No entanto, as legendas dessas duas imagens não identificam a etnia das mulheres, diferente da imagem da mulher mexicana, e nem focalizam em símbolos da pobreza, como o "barraco na favela", na legenda brasileira, ou a galinha e o chão sujo, na legenda da foto americana ${ }^{6}$.

Estas escolhas demonstram processos de biolegitimidade (FASSIN, 2006) já que destacar a pobreza é uma forma de justificar a assistência social. Dessa forma, exibir e relatar a precariedade para assistentes sociais configuram processos biolegitimidores. "Quanto mais deteriorados forem os corpos e os locais de moradia, mais aptos parecem estar os sujeitos a receberem benefícios" (MARQUES, 2018, p. 470). As fotografias documentais e jornalísticas analisadas reforçam essa biolegitimidade, pois elas buscam justamente os indícios visuais que justifiquem a participação dos fotografados em seus determinados projetos sociais. Em relação aos corpos femininos, as fotografias estudadas são marcadas por gestuais e semblantes desolados: "elas são constantemente oprimidas no espaço da casa, encantoadas ou posicionadas de forma a reduzir sua agência física em uma mise-enscène que revela formas de controle patriarcal sobre suas existências" (MARQUES; BIONDI, 2019, p. 91).

A utilização de aberturas a partir de portas, janelas ou laterais de cômodos é constante. Mas essas configurações visuais não trabalham com a idéia de saída e ou entrada de um lugar, no caso das portas, ou da observação de outros horizontes, no caso das janelas. O foco aqui é a cristalização de uma condição precária que justifique a

\footnotetext{
${ }^{6} \mathrm{O}$ estudo que destacamos analisa o processo de racialização nas imagens americanas do FSA. No contexto brasileiro, o processo passa por diferentes mecanismos. Ainda é preciso investigar mais a fundo as particularidades dessa racialização no fotojornalismo brasileiro sobre pessoas empobrecidas.
} 
participação nos programas sociais e/ou apresente possibilidades de superação da pobreza a partir de atividades domésticas.

\section{Imagem 9}

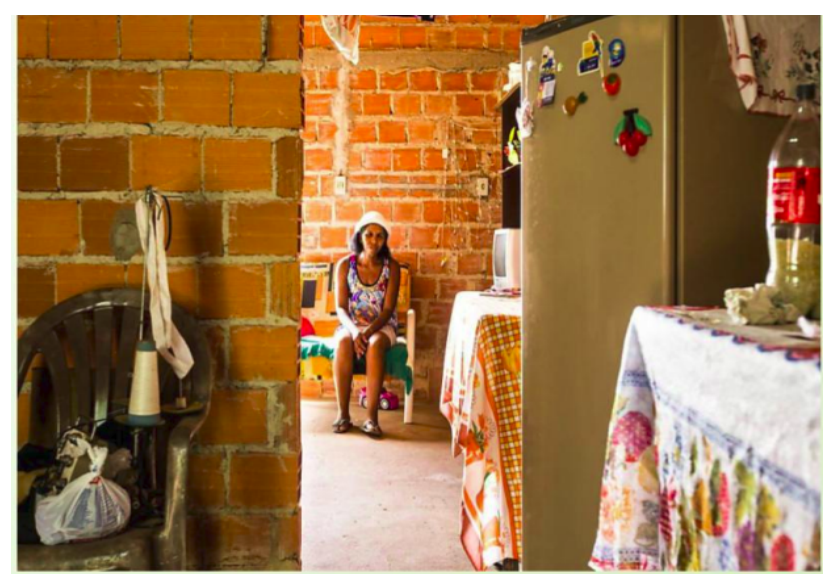

Foto: Eduardo Anizelli/ FolhaPress. Fonte: CARVALHO, Daniel. Famílias deixam pobreza extrema, mas ainda enfrentam dificuldades; leia histórias, Folha de S. Paulo, 03 fev. 2013. Disponível em: https:/ / acervo.folha.com.br/leitor.do?numero=19394\&anchor=5851849\&orig em=busca

\section{Imagem 10}




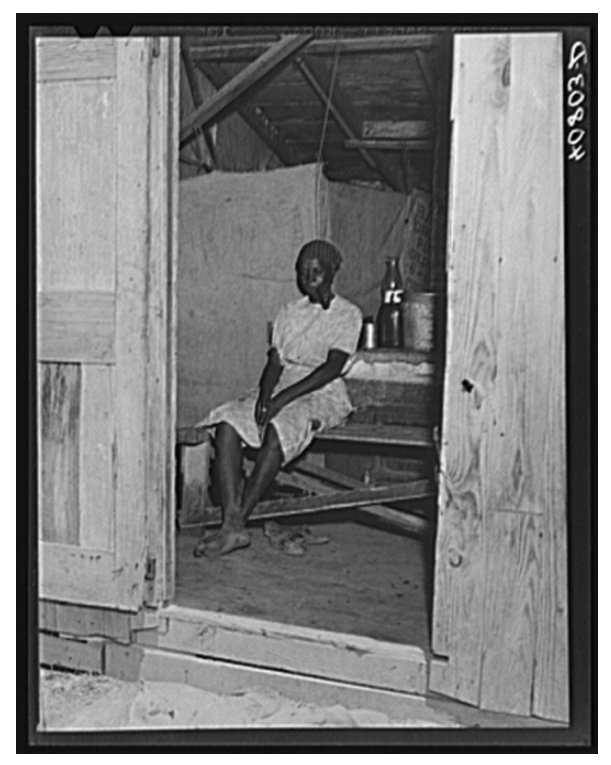

Jack Delano, 1940. Legenda: Migratory agricultural worker in her shack where she lives with eleven others. Belcross, North Carolina. Fonte: http://photogrammar.yale.edu/records/index.php?record=fsa2000022247/P $P$

Nas duas imagens, os enquadramentos verticais são enquadrados dentro própria imagem, de forma que possamos ver os objetos e paredes em volta dos enquadramentos no formato de portas. Estes elementos correspondem a uma iconografia da pobreza, com paredes, cadeiras e sacolas humildes. Ao fundo, as duas mulheres não realizam nenhuma ação, estão petrificadas pelo duplo enquadramento, uma olhando para a câmera e outra para o chão, sem erguer o rosto. É como se a existência delas estivesse intrinsecamente ligada à essa moldura da precariedade que é preservada na imagem: corpos e lares arcaicos, novamente, se tornam um só em tais enquadramentos.

As duas imagens acima têm mais camadas pois, ao utilizarem essa espécie de reflexividade da precariedade, com molduras dentro das molduras, elas estilizam e jogam luz sobre um elemento importante nestes projetos fotográficos e que muitas vezes é invisibilizado: desenvolver uma relação de distanciamento, 
amenizando a proximidade ou a empatia, entre os fotografados e os possíveis leitores dessas imagens. $\mathrm{O}$ distanciamento é uma prolongação da distância social entre os fotografados e os fotógrafos. Susan Sontag foi bem crítica ao FSA devido a essa relação complexa: “O intuito do projeto era demonstrar o valor das pessoas fotografadas. Portanto, definia implicitamente seu ponto de vista: o de pessoas de classe média que precisavam ser convencidas de que os pobres eram mesmo pobres, e de que eram dignos" (SONTAG, 2004, p. 39-40). As fotos do Bolsa-Família estão na mesma linha. Ao focar nos elementos da pobreza, em atos cotidianos incomuns nos centros urbanos (como o cozimento no fogo direto e não no fogão a gás), e na desolação das pessoas fotografadas, essas imagens se tornam retratos de uma realidade exótica distante da classe média. As possíveis aspirações ou sentimentos comuns em diferentes grupos sociais são amenizadas para se intensificar um distanciamento social.

Nessa abordagem, há uma ênfase na solidão das mulheres. O acompanhamento, na maioria das vezes, é por filhas ou filhos, ou seja, ainda dentro do enquadramento doméstico-materno. Imagens de mulheres com o bebês no colo são recorrentes. Dois exemplos claros dessa repetição abaixo:

\section{Imagem 11}




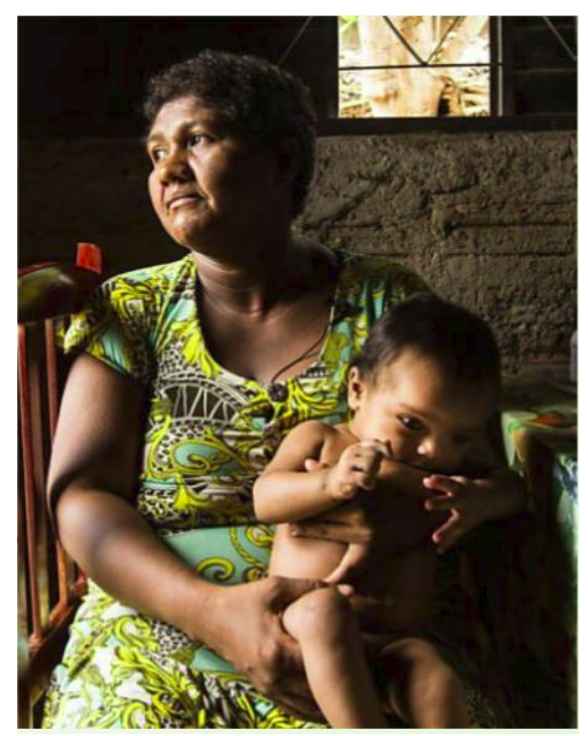

Foto: Eduardo Anizelli/ Folha Press. Fonte: CARVALHO, Daniel. Folha Press. Legenda: Famílias deixam a pobreza extrema, mas ainda enfrentam dificuldades. Folha de São Paulo, 03 fev. 2013. Disponível em: https://acervo.folha.com.br/leitor.do?numero=19394\&anchor=5851849\&orig em=busca 


\section{Imagem 12}

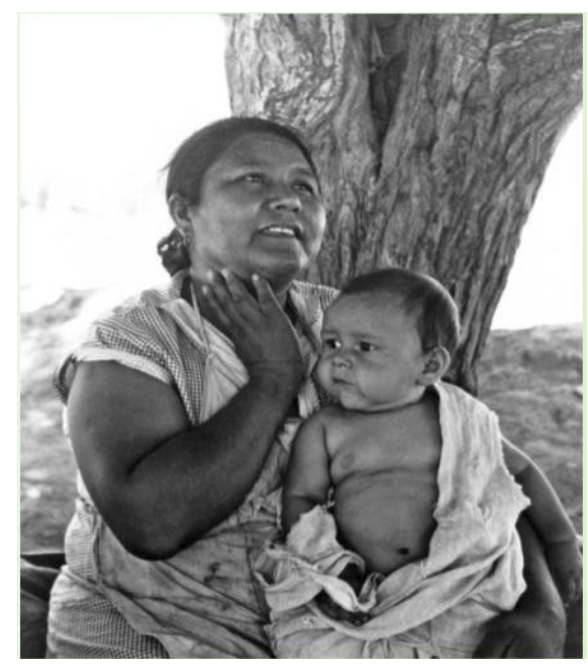

Foto: Dorothea Lange, 1935. Legenda: Mexican mother in California. "Sometimes I tell my children that I would like to go to Mexico, but they tell me 'We don't want to go, we belong here.' (Note on Mexican labor situation in repatriation)." Fonte: https://www.loc.gov/item/2017759126/

Referenciar a maternidade é importante para estes projetos pois o sucesso dos programas sociais geralmente são medidos por critérios considerados maternos. No Brasil, "o governo aponta as mulheres como as "gestoras" responsáveis por garantir o sucesso do Programa através de seu compromisso com o cumprimento das condicionalidades ligadas à saúde e à escolarização de crianças e adolescentes" (MARQUES; FREITAS; OLIVEIRA, 2019, p. 16). fracasso de uma família pode ser medido pela má administração de tarefas gestoras. Uma reportagem que analisamos anteriormente "Efeitos do Bolsa Família após dez anos são desiguais", da Folha de S. Paulo, publicada em 2013 - , chega a fazer um comparativo de sucesso e fracasso entre duas famílias atendidas pelo programa, separando, respectivamente, um grupo digno e um grupo indigno.

No caso do FSA, a entrada das famílias no programa social também passava por processos de "dignificação", já que, como explica Lisa Kaplan (2015), dois critérios eram obrigatórios: a pobreza dos 
assistidos deveria ser causada por forças externas não controladas pelas pessoas, e as famílias deveriam se mostrar aptas a aprender formas "modernas" de vida, que vão desde a questões do cuidado das terras até a organização no lar. Ou seja, algumas famílias que não eram consideradas aptas, ou dignas, de receber a assistência do governo. A educação doméstica era relegada às mulheres e focava em, segundo um manual oficial do governo, em

promover a produção doméstica, conservação e armazenamento de alimentos, melhores dietas, melhor saúde, roupas mais adequadas, habitação e saneamento, fornecimento de equipamentos e móveis domésticos necessários, manutenção de registros, educação, recreação e plena participação na vida da comunidade (GAER apud KAPLAN, 2015, p. 82,)

As imagens mais institucionais do projeto demonstram a importância dessa educação maternal para o projeto.

\section{Imagem 13}

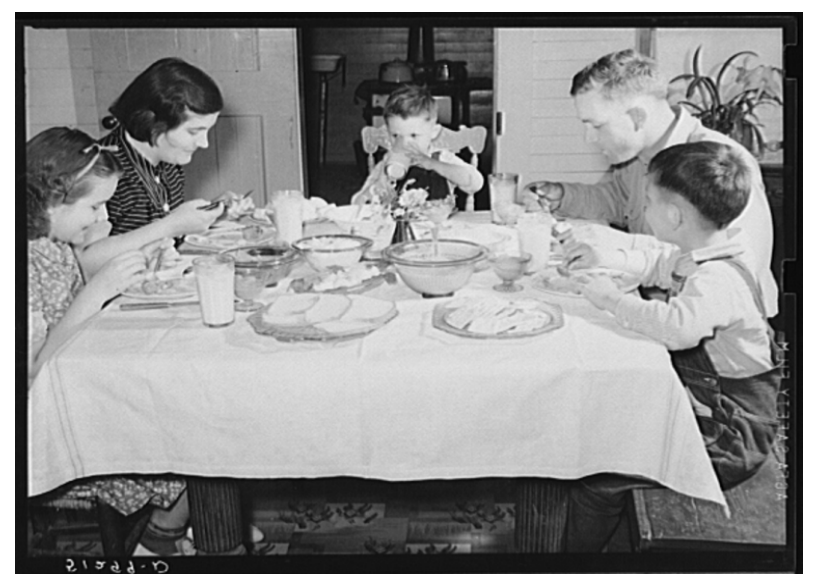

Marion Post Wolcott, 1939. Legenda: Helms family at dinner which consists of roast beef (home canned), turnip greens, potatoes, biscuits, corn bread, butter, milk, peaches, and cake. Coffee County, Alabama. Fonte: http:// photogrammar.yale.edu/records/index.php?record=fsa2000031689/P P 
Segundo Kaplan, o conteúdo e organização da mesa evidencia como a mãe conseguiu prover a comida e saúde para sua família, nos moldes das diretrizes do FSA. "Subjacente há um comentário sobre a capacidade da família de superar a pobreza. O sucesso deles depende fortemente da habilidade da mãe de ter sucesso em seu papel no espaço doméstico" (KAPLAN, 2015, p. 87). O Bolsa-Família não está tão distante dessas diretrizes.

Em um projeto grande como o FSA, com aproximadamente 175 mil negativos, houve muitas produções que não eram completamente institucionais. O problema é que essas outras imagens não eram distribuídas de maneira ampla ${ }^{7}$. Ao observarmos as fotografias consideradas canônicas do FSA, se percebe que a presença dos brancos é majoritária, com essas pessoas formando o arquétipo do trabalhador pobre e digno na época da depressão americana. Isso não significa, necessariamente, que outras realidades não foram registradas. $\mathrm{O}$ nosso próprio artigo apresenta várias imagens desconhecidas do FSA. No entanto, elas fazem parte de um grupo de imagens esquecidas, que somente são observadas por pessoas que imergem intensamente nas milhares de fotografias do projeto.

A relação entre a população branca com uma pobreza digna é problemática, pois, ao tornar comum a relação de outras etnias e grupos sociais com a sujeira e a dificuldade de entrar no mundo moderno, a pobreza desses grupos parece ser uma condição estanque, impossível de mudança. Lisa Kaplan resgata o argumento da historiadora Amanda Coleman de que esse foco coloca a mulher branca como a principal capaz da reabilitação da pobreza, com ela

\footnotetext{
7 Há também a questão da censura: Roy Stryker perfurava diretamente os negativos do material indesejado. O controle rígido ocasionou em brigas com a maioria dos fotógrafos do projeto. Os motivos para essa censura, como coloca Inês Costa (2019), são desconhecidos, pois havia negativos com problemas técnicos que eram danificados, mas também havia materiais sem problemas: "Talvez houvesse muitas fotos do mesmo assunto? Talvez elas não se encaixassem na agenda política da FSA? O fotógrafo mostrou muito de uma posição pessoal? Ou Stryker estava simplesmente com medo de que essas imagens caíssem nas mãos erradas e fossem redirecionadas para uma agenda antigovernamental?" (COSTA, 2019, s/p).
} 
representando uma mulher moderna, o "novo sul". Outras etnias eram centralizadas em outras construções arquetípicas:

Enquanto o corpo da mãe branca se tornou central para a representação visual da pobreza merecedora e da boa maternidade, a mulher mexicana também foi fundamental para a construção da pobreza. As representações visuais de mães mexicanas reforçaram as racializações dos mexicanos nos Estados Unidos por meio de representações limitadas e falta de circulação popular. As mães mexicanas eram invisíveis ou representadas como mães pobres. As construções dominantes das mulheres mexicanas como biologicamente inferiores estavam ligadas à retórica da hiper-fertilidade, declarando as mulheres mexicanas como meios para espalhar doenças, produzindo muitos filhos doentes (KAPLAN, 2015, p. 133).

No caso do Programa Bolsa-Família, as mulheres são constantemente oprimidas por enquadramentos que revelam formas violentas de controle patriarcal sobre suas existências. Tais enquadramentos se efetuam através de uma série de dimensões interligadas: foco na família conjugal, patriarcalismo, divisão desigual do trabalho doméstico, dificuldade em inserir-se no mercado de trabalho, preconceitos de raça, classe e gênero, além da não tematização dessas questões no momento de elaboração das políticas públicas (MARIANO, 2015). Mulheres negras empobrecidas encontram muito mais dificuldades para terem acesso a oportunidades de trabalho remunerado e para conciliar suas necessidades com as tarefas reprodutivas e de cuidado, uma vez que não só suas condições de escolha e de experiência autonômica são reduzidas, como também estão mais vulneráveis à avaliação moral sobre o merecimento ao acesso à renda do programa. Esse julgamento (amparado por ideologias neoliberais) deprecia as mulheres negras e famílias monoparentais chefiadas por mulheres negras que não se mostram capazes de serem "empreendedoras", em contraposição àquelas que 
souberam, por mérito próprio, construir uma forma de vida economicamente autônoma (GEORGES; SANTOS, 2016).

Assim, as imagens fotojornalísticas que conferem visibilidade ao Bolsa-Família e a seus índices de sucesso e fracasso traduzem a emancipação feminina como sucesso econômico individual e meritório, pouco revelando as contingências que atravessam o leque de experiências e escolhas disponíveis às mulheres empobrecidas consideradas a partir de uma dimensão interseccional (MARQUES; MORICEAU, 2018).

\section{Outras possibilidades}

Essas fotografias jornalísticas e documentais não apresentam rupturas ou experimentalismos, com a invisibilidade pautando os enquadramentos sociais elaborados. Dito isto, é possível romper as perspectivas dominantes que norteiam os enquadramentos dessas imagens? Romper é difícil, pois muitas vezes essas fotografias normatizam os corpos em frente da câmera, transformando indivíduos em personagens sociais, utilizando a expressão Bernardet (2003). Mas, além disso, uma fotografia pode ser usada com propósitos diferentes dos autores originais. Sontag destaca que os fotógrafos com preocupações sociais pensam que conseguem transmitir uma verdade estável a partir de suas fotografias, mas "por ser a fotografia sempre um objeto num contexto, tal significado está destinado a se esvair; ou seja, o contexto que molda qualquer uso imediato da fotografia - em especial o político - é imediatamente seguido por contextos em que tais usos são enfraquecidos" (SONTAG, 2004, p.62). Quando nos referimos a rompimentos, não pensamos nesse tipo de reutilização, mas em um elemento presente na imagem, que, de alguma forma, desestabiliza o enquadramento. Vamos a alguns exemplos.

Olhando as duas mães com bebês acima (imagens 11 e 12), percebemos semblantes relativamente sérios. A rigidez se intensifica em outras imagens emblemáticas, como a clássica "Migrant Mother", 
de Dorothea Lange. O sorriso pode se tornar uma forma de flexibilizar essa desolação repetitiva das imagens sociais. Raros nas fotografias do FSA, os sorrisos são mais comuns nas imagens brasileiras. No entanto, ainda assim, eles são sorrisos aparentemente ensaiados, às vezes mirando diretamente a câmera, reforçando a percepção de que aqueles sorrisos são posados para alguém distante.

\section{Imagem 12}

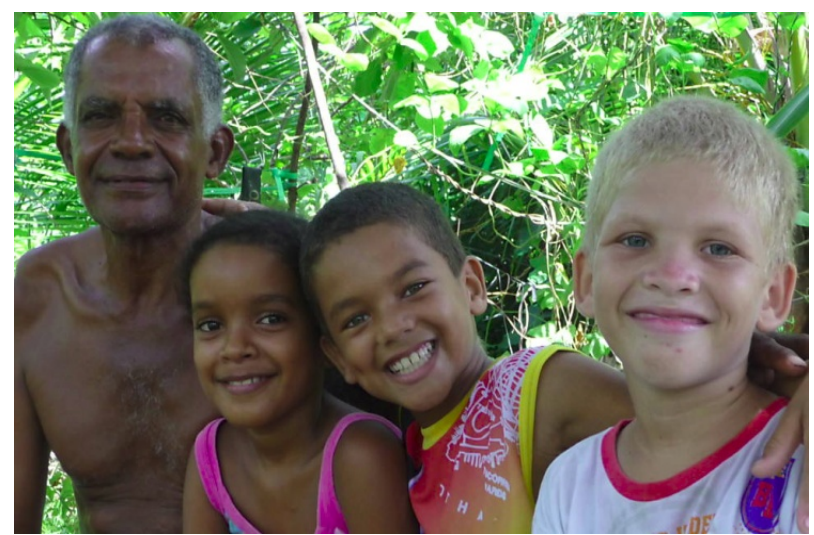

Foto: Andre Felipe/ Folha Press. Fonte: CANZIAN, Fernando. Boyhood Bolsa Família. Folha de São Paulo, p. A2, 12/07/ 2015.

\section{Imagem 13}

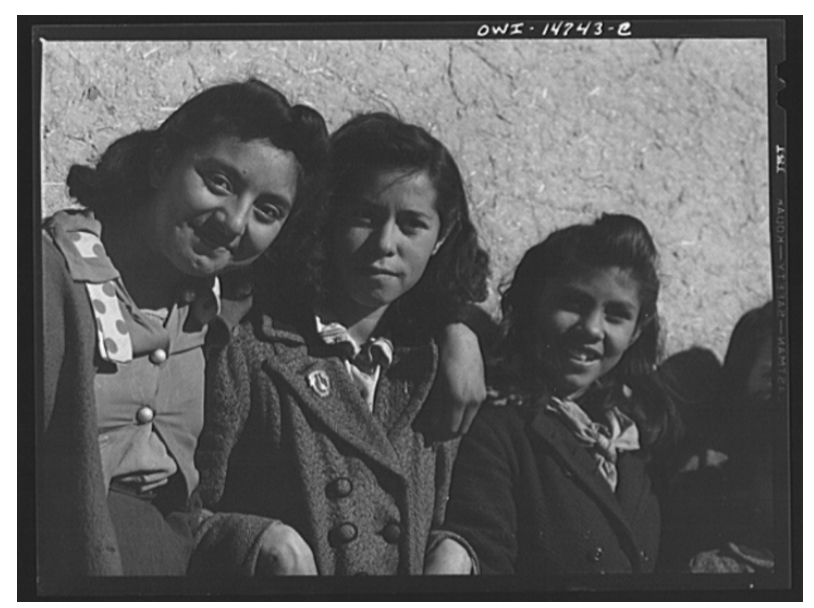


Foto: John Collier, 1943. Legenda: Ojo Sarco, New Mexico. Legenda: Oneroom school in an isolated mountainous Spanish-American community, which has eight grades and two teachers. Afternoon recess. Fonte: http:// photogrammar.yale.edu/records/index.php?record=owi2001016859/ $\mathrm{PP}$ 


\section{Imagem 14}

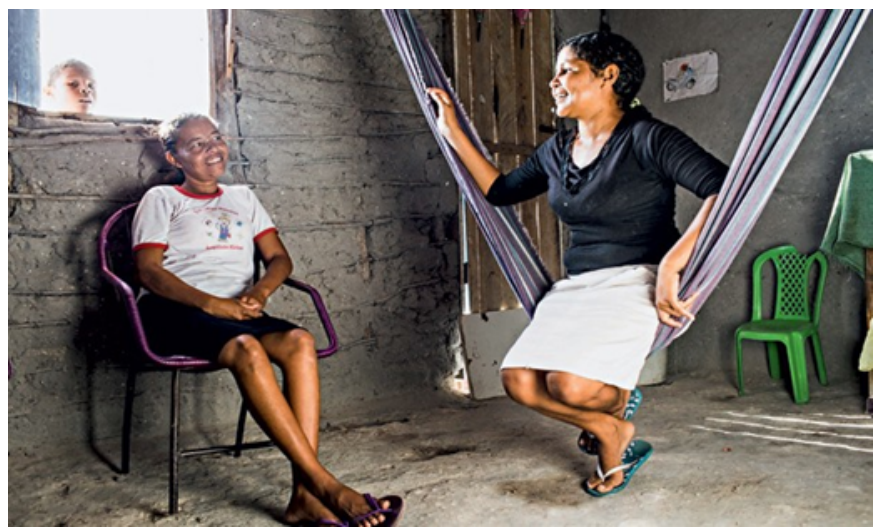

Foto: Guilherme Zauith. Legenda: As vizinhas Sildilene (à esq), de 31 anos, e Regia, de 26, moram no Periá, povoado absurdamente bonito de areias brancas, cajueiros e águas frescas. O sorriso aberto e a recepção calorosa contrastam com suas histórias tristes, de fome e privação. "Meus três meninos mais velhos passaram mais fome", diz Sildi, que ganhava a vida colhendo juçara, um primo do açaí. "Mas aí veio o vale-leite, que ajudou demais, porque eram 3 litros por criança." Regia fugiu de casa aos 12, teve a primeira filha aos 13 e pesava 38 quilos, até conseguir de volta o cartão do Bolsa Família. "Minha filha não tem a mesma vocação [de ter filho cedo]", diz ela, mostrando com carinho os belos desenhos feitos por Raíssa, de 12 anos. "Os meninos não têm notas ruins e são atenciosos na escola.". Fonte: BARBIERI, Cristiane. "Os filhos do Bolsa Família", Época, 2014. Imagem no endereço: https://epocanegocios.globo.com/Informacao/Resultados/noticia/2014/12/ os-filhos-do-bolsa-familia.html

Apesar do sorriso fragilizar o sentimento de tristeza, os sorrisos acima estão, em diferentes graus, cooptados pelo gesto fotográfico. Ainda que alguns carreguem uma personalidade mais intensa - como o menina e a menina que, além de sorrirem, estendem os braços às crianças ao lado -, todos os sorrisos surgem de uma relação com a câmera, uma câmera que está ali para registrar as condições precárias de suas vidas. A fragilização, se existe, é mais amena. Um contraste maior se dá no sorriso não controlado, não ensaiado, mas cristalizado na imagem. Um exemplo abaixo. 


\section{Imagem 15}

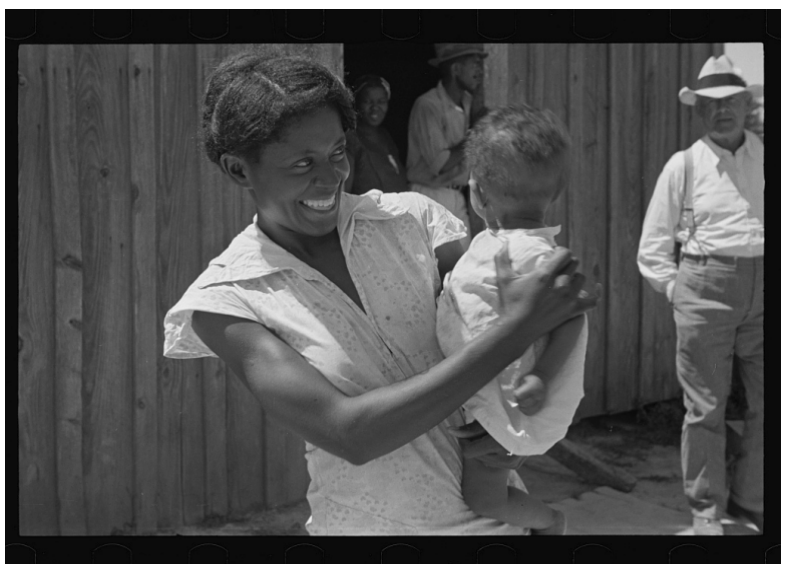

Foto: Arthur Rothstein, 1935. Legenda: Wife and children of Negro tenant farmer, Tupelo, Mississippi. Fonte: http:// photogrammar.yale.edu/records/index.php?record=fsa1997007070/P $\mathrm{P}$

Se compararmos esta mãe com as mães com bebês anteriores, veremos que o contraste é intenso, apesar do conteúdo ser o mesmo. O sorriso aberto da mulher retira a desolação maternal das outras imagens, desde as destacadas aqui até a emblemática de Lange. A espontaneidade fragiliza mais o poder do olhar da câmera. O momentâneo não ganha ares simbólicos, mas tampouco perde a força. A fração de individualidade preservada possibilita ao leitor vislumbrar uma maternidade comum, que pode ter sido presenciada por ele ao rir com a sua filha ou filho, e não uma maternidade precária distante. Se "a prática habitual busca, da maneira como for possível, reprimir na fotografia o seu poder de perturbação e desconcerto (MACHADO, 1984, p. 49), aqui há uma raridade, pois o sorriso desarticula o enquadramento da pobreza ao cristalizar um momento maior do que a moldura da precariedade.

O aspecto vulnerável dessa vida ainda é presente, basta olharmos a casa de madeira ao fundo e o chão, aparentemente, não asfaltado. No entanto, essa vulnerabilidade não é total na imagem e nem define completamente a mãe e o filho no centro da imagem. Eles 
têm uma vida própria que não foi completamente enquadrada: o bebê é tão autônomo que está com a cabeça na direção contrária da lente. Essa imagem nos aponta uma fissura, um intervalo entre o corpo fabricado "para a pose" e o corpo fabricado "na pose". Contudo, a margem de negociação entre o olhar do fotógrafo e a postura de recusa do fotografado é ainda pequena. Na composição da pose,

O recorte visual é intencional, a composição é rigorosa e padronizada de modo a disciplinar o corpo e a reduzir incertezas e ambiguidades. Há um contrato subjacente entre o sujeito e o fotógrafo. É um movimento duplo de anúncio e renúncia do sujeito. Uma passa a existir de acordo com o conjunto de normas visuais, na imagem e no papel fotográfico. O outro é negado justamente por esses conjunto de ações agrupados no protocolo, tanto social como visual, para fabricar uma idealização (SILVA JR., 2017, p. 60)

Entretanto, a mulher nessa imagem ainda está no âmbito da maternidade e do lar, pois ela está com seu filho e próxima de uma casa. Na legenda, não é apontado o seu nome, somente que ela é a esposa de um fazendeiro negro. Identificar nessas imagens a mulher em outras âmbitos é mais raro ainda. Como pontuamos, o sucesso da mulher, em ambos os projetos, é medido a partir da forma como ela consegue administrar o seu lar. O sucesso feminino para além da casa não é tão comum nesses enquadramentos. Kaplan (2015) comenta que até o trabalho físico realizado momentaneamente pelas mulheres nas fazendas dos EUA na depressão, não eram focalizados pelas imagens mais institucionais do FSA: o foco era a casa. Vamos analisar algumas raras possibilidades a seguir.

Como já dito, nessas fotografias, o enquadramento dentro do enquadramento, principalmente os que tem o formato de portas, servem como cristalizadores da condição doméstica. Quando as mulheres inseridas nessas molduras estão em posições tristes, as laterais das "portas" dentro da imagem têm uma função opressora. Ao redor dessas molduras, não está somente o edificação do lar, mas o peso de enquadramentos sociais que buscam registrar a mulher 
somente dentro do lar. Diante dos poucos registros de mulheres em outras atividades, imagens que rompam determinados estereótipos são mais raras, principalmente nas imagens brasileiras do BolsaFamília. No caso do FSA, devido a extensão do projeto fotográfico, é possível encontrar alguns exemplos mais complexos.

\section{Imagem 16}

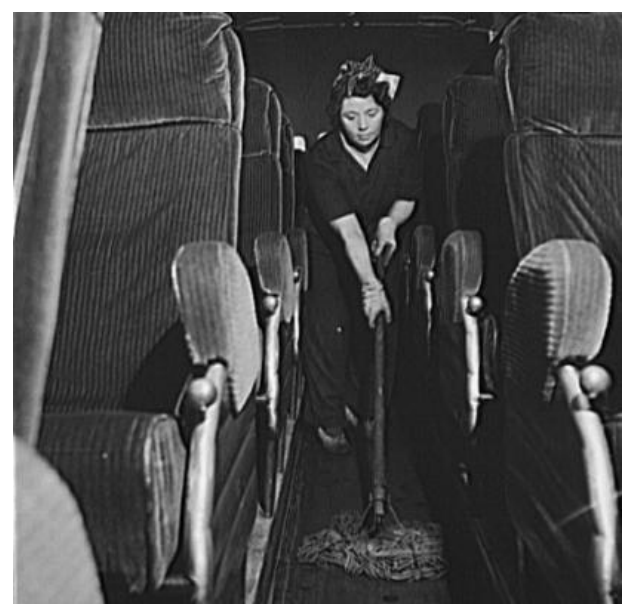

Foto: Esther Bubley. Legenda: Woman cleaning the interior of a Greyhound bus.

Há um enquadramento vertical dentro do enquadramento, semelhante às imagens 9 e 10. Mas a porta, aqui, se torna um corredor a partir do enfileiramento das cadeiras, e o espaço é outro: um ônibus. Já a mulher não está parada, mas limpando um transporte público. Ela exerce uma função específica em um local específico, e não obedece um arquétipo social. No entanto, existe uma obscuridade latente na imagem, com a mulher ficando no final desse corredor de penumbras, em um espaço momentaneamente isolado, mas que, em breve, ficará lotado de pessoas. Ou seja, há um diálogo estético e social com a solidão, mas em outro ambiente, em outra realidade. A análise de Jacqueline Ellis relaciona esses paradoxos com uma nova fase da fotografia no cenário da Segunda Guerra Mundial: 
Ao tirar esta fotografia em tal contexto, Bubley estabeleceu a presença essencial, mas inevitavelmente ausente, de uma mulher da classe trabalhadora nas narrativas oficiais de informações do tempo de guerra. Ao mesmo tempo, enquanto Bubley foca na luz que incide sobre os braços da mulher, ela destaca a maneira como a mulher empurra o esfregão com certa força e determinação. Há um impulso definido para a frente que contrabalança seu movimento para trás. Ao capturar essa dinâmica de oposição, Bubley permitiu à mulher da classe trabalhadora subverter e invadir silenciosamente o espaço físico ocupado pelos passageiros patrióticos, contexto que foi fundamental para a fotografia documental na década de 1940 (ELLIS, 1996, p. 84).

Ou seja, há uma mudança de paradigmas. Institucionalmente, o FSA realmente mudou de foco, saindo da construção de uma pobreza digna e honrada nos anos 1930 para discursos mais nacionalistas e patrióticos nos anos 1940, refletindo o contexto da Segunda Guerra Mundial. Mas, dentro dessa mudança, Esther Bubley, como demonstra Jacqueline, soube romper com os discursos das duas décadas, apresentando imagens que conseguiam falar por si e não repetir estereótipos. Vamos fazer mais uma análise comparativa para abordar esse rompimento.

A mulher sentada e isolada é bem comum nas fotografias do Bolsa Família e do FSA, se intensificando a relação entre mulher e ambiente doméstico, e o seu isolamento nesse espaço. Dois exemplos abaixo. 


\section{Imagem 17}

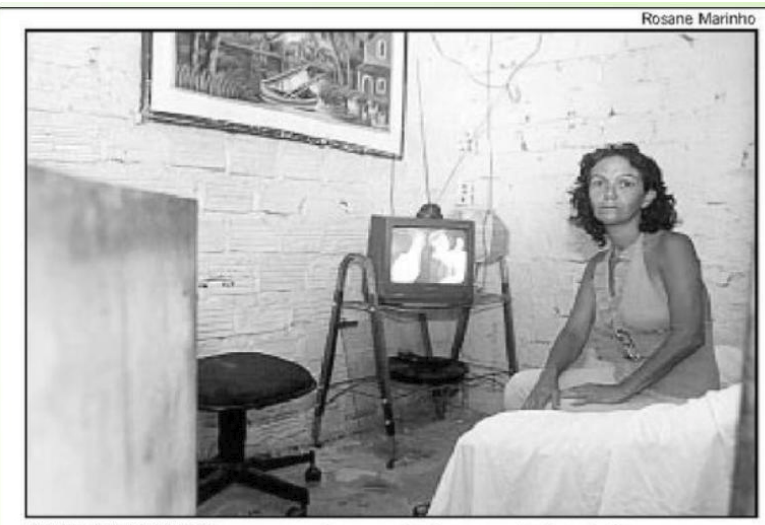

MARIA DO SOCORRO na casa onde mora desde que saiu da palafita

Foto: Rosane Marinho/ O Globo. Fonte: RIBEIRO, Efrém. Um ano depois, nos emblemas da miséria -, O Globo, O. País, 11/01/04. Legenda: Maria do Socorro na casa onde mora desde que saiu da palafita

\section{Imagem 18}

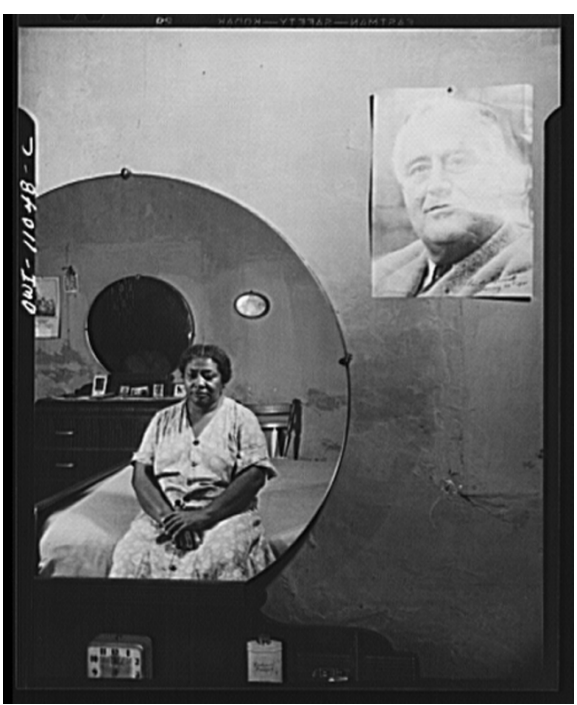

Foto: Gordon Parks, 1943. Legenda: Washington (southwest section), D.C. Negro woman in her bedroom. Fonte: http:// photogrammar.yale.edu/records/index.php?record=owi2001013616/ PP 
As duas imagens têm configurações visuais bem distintas: na brasileira, o ponto de vista do fotógrafo é mais invisibilizado, já na americana, há uma certa reflexividade, com a câmera apontando o reflexo de um espelho. Mas, em ambos, há mulheres entristecidas sentadas em cômodos humildes, com objetos externos que chamam a atenção (uma televisão e um retrato de Franklin Roosevelt), apesar da indiferença das mulheres para estes elementos. Essa passividade é presente no corpo das mulheres, nos rostos com pouca expressão e distantes, nas mãos e braços sem "ação". As legendas das imagens destacam elementos do espaço e não uma ação ou sentimentos das mulheres retratadas. Agora vamos a uma imagem de Esther Bubley.

\section{Imagem 19}

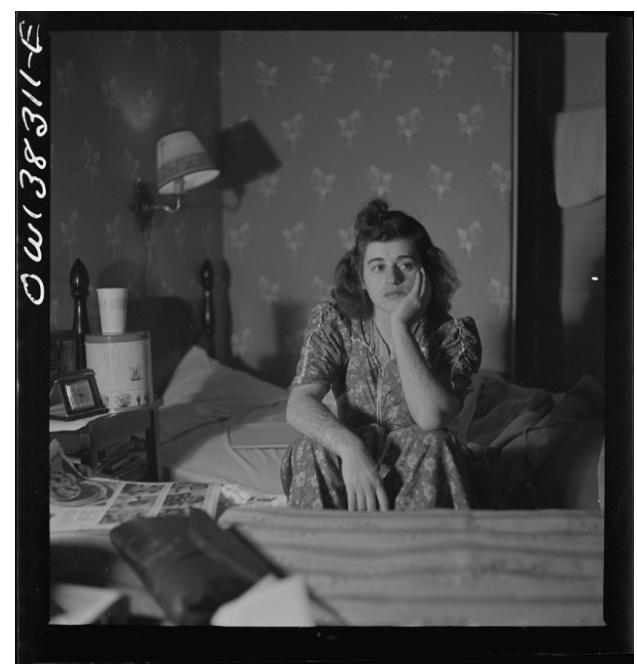

Esther Bubley, 1943. Legenda: Washington, D.C. Pearl Ginsburg refused to have her boarding house rent raised. Fonte: https://www.loc.gov/item/2017862338/

Novamente uma mulher sentada em um local humilde. No entanto, rapidamente nos chama a atenção o braço levantado e a mão no rosto, um gesto incomum nas fotografias do FSA, transmitindo, junto com o olhar atravessado, um sentimento de incômodo e preocupação. Na legenda, é informado que a mulher se recusa a ter o aluguel aumentado. A descrição é sintomática pois ela guia atenção do 
espectador, mas não para um elemento humilde do espaço, não para uma condição de vulnerabilidade, mas para uma posição de enfrentamento da pessoa fotografada. E esse enfrentamento não é contra uma força externa e simbólica, como a pobreza no geral, mas contra uma realidade bem específica: o aumento de aluguel de uma pensão feminina. A vulnerabilidade está presente, mas ela não elimina a capacidade de agência da mulher no centro. Os elementos mais destacados na imagem (a mão no rosto e o olhar preocupado) e na legenda (a "recusa" da mulher) representam mais uma ação do que uma passividade, fragilizando os paradigmas de pobreza essencialista e passiva que foram cristalizados anteriormente pelas imagens mais emblemáticas do FSA.

As fotografias de Esther Bubley na pensão de mulheres ou na entrada de uma loja de sapatos, no último dia em que um cupom de compra poderia ser usado, demonstram formas de afetividade, de desejo e de consumo que vão além das questões domésticas, familiares e maternas. Ao se deslocar para outras realidades suburbanas, diferentes da pobreza rural da Depressão, a fotógrafa registrou momentos de cotidiano que não tem muitos paralelos nas imagens do próprio FSA e, principalmente, no fotojornalismo do Bolsa-Família, este marcado por uma cristalização dos corpos, geralmente passivos. É como se para os corpos fotografados só existisse a possibilidade de uma vida precária, sem cultura, sem conhecimento e sem momentos lúdicos. Esta é a forma como os leitores dessas imagens enxergam a vida das pessoas em frente à câmera, que, devido ao caráter homogeneizante do operador, transforma um recorte, focado na vulnerabilidade, em uma realidade, pelo menos para aqueles distantes. A maioria das fotografias não nos convidam a nada, somente a leituras rápidas. As exceções existem, mas são raras, tanto no Bolsa-Família quanto nas imagens do FSA dos anos 1930. É interessante registrar que, nos dois casos, as diferenças de classe e gênero entre fotógrafos e fotografados interfere nas imagens. Notamos que as imagens feitas por 
fotógrafas mulheres costumam romper com enquadramentos vitimizantes. Um exemplo final abaixo. 


\section{Imagem 20}

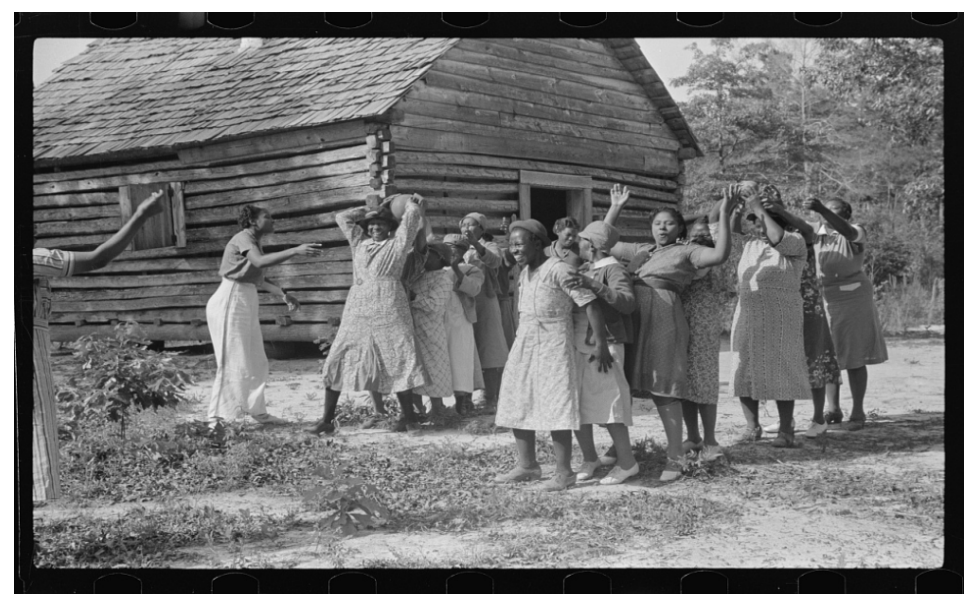

Foto: Marion Post Wolcott, 1939. Legenda: Juanita Coleman helps during recreation time for adult class. In the church she teaches them to read and write and to discuss any interests and problems. Gees Bend, Alabama. Fonte: http://photogrammar.yale.edu/records/index.php?record=fsa1998012453/P $\underline{\mathrm{P}}$

De certa forma, há aqui tudo o que não havia nas imagens anteriores: uma descentralização dos corpos, várias sorrisos espontâneos e um clima de diversão. As mulheres formam uma linha de atenção que nos leva para a natureza, e não para uma casa. Na legenda, é identificado que aquele é um momento de recreação de uma turma de adultos. Na igreja, Juanita Coleman ensina as mulheres a escrever e ler e discutir quaisquer interesses e problemas. A falta de uma composição harmoniosa só intensifica o caráter momentâneo e lúdico do registro. E a legenda só amplifica as possibilidades de vida daquelas mulheres na imagem, mostrando interesses que vão além do âmbito doméstico e materno. A fotografia não está em uma linha experimental, mas rompe fortemente com os enquadramentos patriarcais de um tipo de fotografia social que estava se consolidando naqueles tempos e ainda é visível nos dias hoje, como se percebeu no fotojornalismo do Bolsa-Família. 


\section{Considerações finais}

O aparecer de mulheres empobrecidas nas imagens fotográficas envolve uma operação delicada de questionar o enquadramento hierárquico e consensual, de interpelá-lo em busca das fissuras que indicam que a moldura não consegue determinar de forma precisa o que vemos, pensamos, reconhecemos e apreendemos. No lugar de discursos de causalidade e de apagamento das sutilezas e texturas das experiências, é importante apostar na escolha de outro enquadramento para "ler" os enunciados, para abrir intervalos narrativos que permitam duas ações simultâneas: criar uma narrativa intervalar e, através dos intervalos, permitir aos espectadores uma outra forma de legibilidade do tempo e do comum. Para fazer figurar os povos vulneráveis na imagem é importante encontrar os relatos que permitem tornar sensível uma aproximação, um avizinhamento mais demorado entre espectador e alteridade presente na imagem (OLIVEIRA; MARQUES, 2019).

O entrelaçamento das imagens em uma montagem dissensual produz um trabalho de fabricação de uma cena e confere destaque ao gesto de "jogar com a ambiguidade das semelhanças e a instabilidade das dessemelhanças, operar uma redisposição local, um rearranjo singular das imagens circulantes" (RANCIÈRE, 2012, p.34). Esse trabalho de mudança dos modos de aparição, das coordenadas do representável e das formas de sua enunciação altera quadros, ritmos e escalas, proporcionando outras formas de apreender o visível e sua significação.

Essa dimensão da operação de montagem que envolve dialetizar o visível e tornar sensível nos interessa mais de perto, porque permite a indecidibilidade do espectador, que vacila antes de emitir um julgamento moral definitivo e taxativo diante de uma imagem. Sob esse aspecto, tornar sensível é também desarmar o olhar e fazer trabalhar o saber imaginativo, potencializando a imaginação 
diante de uma "máquina de desmontagem do olhar", de interrupção das explicações hegemônicas. A dialetização do visível é, portanto, um processo que exige a interpelação constante do espectador, solicitando outro imaginário e uma forma de consideração que se posiciona contra o apagamento das formas de vida precárias no interior das imagens.

\section{Referências}

BOURDIEU, P.; BOURDIEU, M-C. O camponês e a fotografia. Revista de Sociologia e Politica, v. 26, p. 31-39, 2006.

BUTLER, J. Quadros de guerra: quando a vida é passível de luto? Rio de Janeiro: Civilização Brasileira, 2018.

COSTA, Inês. Killed negatives. ZUM, v. 16. 2019. Disponível em: https:/ / revistazum.com.br/en/revista-zum-16/negativoseliminados/. Acesso em: 29 ago. 2020.

DIDI-HUBERMAN, George. Coisa pública, coisa dos povos, coisa plural. In: NAZARÉ; Leonor; SILVA, Rodrigo (Org.). A República por Vir: Arte, Política e Pensamento para o Século XXI. Lisbonne: Fondation Calouste-Gulbenkian, 2011. p.41-70.

DIDI-HUBERMAN, Georges. Peuples en larmes, peuples en armes. Paris: Éditions de Minuit, 2016.

DIDI-HUBERMAN, Georges. Peuples exposés, peuples figurants, L'Oeil de l'Histoire. 4. Paris: Éditions de Minuit, 2012.

DIDI-HUBERMAN, Georges. Quando as imagens tocam o real. Pós, Belo Horizonte, v. 2, n. 4, p. 204-219, nov. 2012.

ELLIS, Jacqueline. Revolutionary Spaces: Photographs of Workingclass Women by Esther Bubley 1940-1943. Feminist Review, n. 53, p. 74-94, 1996.

GEORGES, I.; SANTOS, Y. As novas politicas sociais brasileiras na saúde e na assistência. Belo Horizonte: Fino Traço, 2016.

KAPLAN, Lisa. "Introducing America to americans": FSA Photography and the construction of racialized and gendered citizens. 2015. Tese de doutorado - Bowling Green State University, Ohio, 2015. 
MACHADO, A. A ilusão especular: introdução à fotografia. São Paulo: Brasiliense; Rio de Janeiro: Instituto Nacional da Fotografia. 1984.

MARIANO, Silvana. A focalização e as condicionalidades do Programa Bolsa Família afirmam a noção de direito social e contribuem para a formação de sujeitos de direitos?. In: MIGUEL, L.F; BIROLI, F.; MARQUES, D.; MACHADO, C. (Org.). A democracia face às desigualdades: problemas e horizontes. São Paulo: Alameda, 2015. v. 1. p. 275-305.

MARQUES, A. C. S. A política das imagens e a pobreza. Mulheres do Bolsa-Família no fotojornalismo entre 2003 e 2013. Sur le Journalism, v. 6, p. 38-55, 2017.

MARQUES, A.; MORICEAU, Jean Luc. Cadrage biopolitique des personnes appauvries par l'image photographique: entre gouvernement des corps et biopuissance des modes de vie. In: AYOUB, C. (Ed.). Monde arabe et Amérique latine: confluence des dynamiques sociales. Paris: L'Harmattan, 2018. p. 22-39.

MARQUES, Angela; BIONDI, Angie. O doméstico tem um gênero: figurações de mulheres empobrecidas no discurso visual do fotojornalismo. Revista Latinoamericana de Ciencias de la Comunicación, v. 16, n. 30, p. 87-99, 2019.

MARQUES, Angela; FREITAS, Viviane; OLIVEIRA, Cícero. Fotojornalismo e controle biopolítico: enquadramentos de mulheres e famílias beneficiadas pelo Programa Bolsa-Família. Âncora: Revista Latino-americana de Jornalismo, v. 6, n. 2, 2019.

MARQUES, Angela; Luís, MARTINO. Entre o digno e o precário: enquadramento biopolítico de mulheres em fotografias jornalísticas sobre o Programa Bolsa-Família. Bakhtiniana, v. 13, n. 1, p. 33-60, 2020.

RANCIÈRE, J. Le travail de l'image. Multitudes, n. 28, p.195-210, 2007.

RANCIÈRE, J. O espectador emancipado. São Paulo: Martins Fontes, 2010.

RANCIÈRE, Jacques. “O desmedido momento". Serrote, n. 28, 2018a. 
RANCIÈRE, Jacques. «Un soulèvement peut en cacher un autre ». In: DIDI-HUBERMAN, Georges. Soulèvements. Paris: Gallimard, Jeu de Paume, 2016. p.63-70.

RANCIÈRE, Jacques. Aisthesis: scenes from the aesthetic regime of art. London: Verso, 2013.

RANCIÈRE, Jacques. La Méthode de la scène. Paris: Éditions Lignes, 2018b.

RANCIÈRE, Jacques. Le travail des images. Conversations avec Andrea Soto Calderón. Dijon: Les Presses du Réel, 2019.

RANCIÈRE, Jacques. Les bords de la fiction. Paris: Éditions du Seuil, 2017.

RANCIÈRE, Jacques. Les temps modernes. Paris: La Fabrique, 2018c.

RANCIÈRE, Jacques. $O$ destino das imagens. Rio de Janeiro: Contraponto, 2012.

RANCIÈRE, Jacques. The method of equality: an answer to some questions. In: ROCKHILL, Gabriel; WATTS, Philip (Ed.). Jacques Rancière: History, Politics, Aesthetics. Duke University Press, 2009. p. 273-288.

OLIVEIRA, Cícero; MARQUES, Angela. Enquadramentos da precariedade no lar:uma análise comparativa entre imagens do Farm Security Administration e do Bolsa-família. EIKON, n. 6, p. 62-74, 2019.

SILVA JR., José Afonso da. O retrato da tristeza. A representação do sujeito público na carte-de-visite oitocentista na Coleção Francisco Rodrigues. FAMECOS, v. 24, n. 2, p.54-68, 2017.

SONTAG, Susan. Objetos de melancolia. In: Sobre fotografia. São Paulo: Cia. das Letras, 2004. 